\title{
Development of Domestic Gas Supply Obligation Model for Efficient Gas Utilisation in Nigeria
}

\author{
Kenneth Nduka, Charley Iyke Anyadiegwu, Ugochukwu Ilozuruike Duru, \\ Ubanozie Julian Obibuike, Stanley Toochukwu Ekwueme*
}

Department of Petroleum Engineering, Federal University of Technology, Owerri (FUTO), Nigeria

\author{
Email address: \\ stanleyekwueme@yahoo.com (S. T. Ekwueme) \\ ${ }^{*}$ Corresponding author
}

\section{To cite this article:}

Kenneth Nduka, Charley Iyke Anyadiegwu, Ugochukwu Ilozuruike Duru, Ubanozie Julian Obibuike, Stanley Toochukwu Ekwueme. Development of Domestic Gas Supply Obligation Model for Efficient Gas Utilisation in Nigeria. International Journal of Oil, Gas and Coal Engineering. Vol. 8, No. 2, 2020, pp. 35-39. doi: 10.11648/j.ogce.20200802.11

Received: February 9, 2020; Accepted: February 19, 2020; Published: March 2, 2020

\begin{abstract}
In the past government preferred to sell natural gas to international users rather than keep it for local utilisation. The possible explanation to this is that more revenue is accruable from the sale of the natural gas internationally than locally, and market instabilities further limits the choice of local supply of natural gas. This reason has led to scarcity of natural gas for local consumption leading to limited industrial progress because most industries utilise natural gas. To curb the situation, a method must be developed for proper allocation of natural gas domestically such that gas availability and assurance of local market is guaranteed. In this paper, a domestic gas supply obligation model is developed. The model was developed by determining mathematical equations relating the gas reserve, gas utilised, gas flared and gas demanded of a company. The model seeks to enhance optimum gas supply for allocation to the strategic sectors of the economy. The model is useful in mopping up gas from the gas producing multinationals and indigenous companies and redistributing it to the strategic users. The model works out the quota of gas quantities that primary producers should mandatorily supply to the national reserve. The work developed a monitory system that will persuade gas producers for compliance to the domestic gas supply obligation. The paper encouraged gas flare down management by ensuring that gases are adequately distributed and utilised locally. The model ensures that government do not lose out rightly by ensuring that each company supplies that quantity of gas it is obligated to.
\end{abstract}

Keywords: Domestic Gas, Gas Utilisation, Supply Obligation, Obligatory Ratio, Model Development

\section{Introduction}

Nigeria holds the 9th largest gas resources in the world with around $187 \mathrm{TCF}$ of proven reserves. The potential for additional gas reserves is very high and is estimated at about $600 \mathrm{TCF}[1,2]$. The gas resources are primarily located in the prolific Niger Delta region in the southeast of the country. The gas is typically of high quality, rich in natural gas liquids and low in impurities. Despite these potentials, the Nigerian gas sector is relatively underdeveloped, with particularly low level of domestic utilization. The EIA report conducted by the PPPRA Nigeria in 2014 shows that the demand for natural gas in Nigeria has grown substantially from domestic, regional and export markets. Domestic demand growth is driven principally by the needs of the power sector, industrial consumers and manufacturers that need gas as their feed stock. Regional growth is mainly from the West African subregion driven by the recently completed West African gas pipeline project [3].

Rising gas prices in key international markets however continue to create a preferential pull for exports. Consequently, there is a disproportional focus by gas suppliers in the country for LNG projects $[4,5]$. This creates an anomaly in Nigeria where there is a significant shortfall in the availability of gas for domestic utilization. The continued shortfall directly threatens the economic aspiration of the nation which if unchecked may result in Nigeria supporting the development of the economies of the industrialized nations at the expense of its own economy [6, 7]. Nigeria needs to demonstrate availability and affordability of gas or 
else risk losing these industries to competing nations like Egypt, Trinidad, etc. The scale of demand growth relative to supply growth creates an immediate availability challenge. The domestic demand sectors such as electric power, fertilizer, methanol, and etc. have varying capacity to bear gas prices. For example, the Nigeria power sector has a lower gas price threshold than a methanol industry. Government is however, keen to stimulate the growth of all these sectors. Timely availability, affordability and commerciality of natural gas supply are critical precondition for realizing the government's aspiration for the domestic economy $[8,9]$.

The Nigerian government in 2007 officially introduced the Gas Master Plan for natural gas in the country. The plan calls for increased gas use throughout Nigeria and provides fiscal incentives for oil producing operators to maximize gas output and stop the flaring of associated gas. The Gas Master Plan plans emphasis on domestic markets as opposed to exports. To ensure the success of the initiative, the federal government gave the oil companies directives to make available to the domestic market at least $50 \%$ of their total gas production. This is the Domestic Gas obligation.

\subsection{Literature Review}

Ogwo [10], stated that Oil and Gas production in Nigeria is undertaken under Oil Mining Leases (OML); there is no Gas-specific license. Okparaojiako [11], stated that the demand for gas in the power sector is very high because power supply stands to be the pillar of economic growth in any country, be it large scale industries or otherwise. Therefore generating the required power to boost economic activities in Nigeria has been of kin interest to the Government as to achieve the bench mark of vision 2020 . Okparaojiako [11], also emphasised that there is enormous reasons for developing gas based industries in Nigeria. The projected demand for based industries is estimated to grow from the current low levels to reach over $1 \mathrm{bscf} / \mathrm{d}$ by 2020 . Ogwo [12] stated that there are more than one hundred existing, ongoing and planned gas utilization projects in Nigeria. These projects are undertaken by the government, multinational Oil companies, JVs or under Public-Private partnership (PPP). Some of these projects are geared towards making gas available for domestic use, while some will actually consume gas. Ogwo [13] On equivalent gas pricing stated that a good number of factors determine the gas supply which includes: cost of gas production, availability of storage facility, adequate transmission equipment, sufficient technology to harness the associated gas, enabling government policy, adequate market for the gas supply and peaceful environment. Kazeem et al [14], stated that individual fields do not produce enough associated gas to be economic. The author stated further that an expensive network of compression facilities and pipeline must be needed to link these scattered fields to collect enough gas for a typical industry. Therefore, it was not surprising that when the first small volumes of gas started flowing to Nigeria industry in the 1960s they were from gas reservoirs. This gas was cheaper and more reliable source because they are produced at high pressure and do not depend on oil production

\subsection{Research Objectives}

1. To develop a model for domestic gas supply obligation in Nigeria.

2. To develop strategies to ensure Oil and Gas companies meet with the domestic gas obligation.

3. To increase viability of domestic gas to both suppliers and end users.

4. To develop equation that will handle cases of gas deficiency for each gas producer

\section{Methods}

The government of Nigeria, through the Department of Petroleum Resource aggregates gas by simple proportion of the quantity of gas in the reservoir, produced and flared by the operating companies. This is done in line to meet up with the domestic gas obligation. For a given domestic volume of gas demanded, the domestic gas obligation ensures that 50 percent of the demand comes from the gas reservoir of companies, 20 percent of the demand comes from gas utilised by companies and 30 percent of the demand comes from gas flared by the operating companies.

Model Development

The domestic gas obligation shall be fit into mathematical model for easy implementation.

For operating companies $1,2,3 \ldots n$, where ' $n$ ' is any company,

Let domestic volume of gas demanded $=\mathrm{D}(\mathrm{MMscf} / \mathrm{Yr})$.

Individual Company Obligated Gas Volume $=D_{n}$, (MMscf/Yr).

Individual Company Gas Reserve $=G_{n}$, (MMscf),

Individual Company Volume of Gas Utilised $=U_{n}$, (MMscf/Yr), And

Individual Company Volume of Gas Flared $=F_{n}$, (MMscf/Yr),

The total Gas Reserve for the operating companies is as follows

$$
G_{1}+G_{2}+\cdots+G_{n}=\sum_{i=1}^{n} G_{n}
$$

The total volume of gas Utilised by the operating companies is as follows,

$$
U_{1}+U_{2}+\cdots+U_{n}=\sum_{i=1}^{n} U_{n}
$$

The total volume of gas flared by the operating companies $=$

$$
F_{1}+F_{2}+\cdots+F_{n}=\sum_{i=1}^{n} F_{n}
$$

The mathematical expression for the domestic gas obligation in terms of quantity becomes

$$
D_{n}=D\left(0.5 \frac{G_{n}}{\sum_{i=0}^{n} G_{n}}+0.2 \frac{U_{n}}{\sum_{i=0}^{n} U_{n}}+0.3 \frac{F_{n}}{\sum_{i=0}^{n} F_{n}}\right)=D \times Y_{n}
$$


Where,

$$
\begin{gathered}
Y_{n}=0.5 \frac{G_{n}}{\sum_{i=0}^{n} G_{n}}+0.2 \frac{U_{n}}{\sum_{i=0}^{n} U_{n}}+0.3 \frac{F_{n}}{\sum_{i=0}^{n} F_{n}} \\
D=D_{1}+D_{2}+\cdots+D_{n}=\sum_{i=1}^{n} D_{n}
\end{gathered}
$$

$Y_{n}$ is the gas obligation contribution ratio for company $\mathrm{n}$.

The generalised equation of domestic gas supply obligation for any company is

$$
D_{n}=D\left(G_{r} \frac{G_{n}}{\sum_{i=0}^{n} G_{n}}+U_{r} \frac{U_{n}}{\sum_{i=0}^{n} U_{n}}+F_{r} \frac{F_{n}}{\sum_{i=0}^{n} F_{n}}\right)=D x Y_{n}
$$

The generalised equation of the gas contribution ratio for any company

$$
Y_{n}=G_{r} \frac{G_{n}}{\sum_{i=0}^{n} G_{n}}+U_{r} \frac{U_{n}}{\sum_{i=0}^{n} U_{n}}+F_{r} \frac{F_{n}}{\sum_{i=0}^{n} F_{n}}
$$

Recall, Domestic Gas Supply Obligation of company n,
$=D_{n}$, Actual Volume of gas supplied by the company, $\mathrm{n}=$ $D_{n_{i}}$, then the gas supply deficit for company n, $D_{D_{n}}$ becomes;

$$
D_{D_{n}}=D_{n}-D_{n_{i}}
$$

The total gas deficiency $D_{D}$, becomes

$$
D_{D}=\sum_{1}^{\mathrm{n}}\left(D_{n}-D_{n_{i}}\right)
$$

\section{Results and Discussion}

The result below was obtained from the model developed. We shall determine the company's contributory ratio, their

\begin{tabular}{|c|c|c|c|c|c|c|c|c|}
\hline Company & $\begin{array}{l}\text { Reserves, } G_{n} \\
(\text { TCF) }\end{array}$ & $\begin{array}{l}\text { Utilisation, } U_{n} \\
(\mathrm{TCF} / \mathrm{yr})\end{array}$ & $\begin{array}{l}\text { Flared, } \\
F_{n}(\mathrm{TCF} / \mathrm{yr})\end{array}$ & $\begin{array}{l}\text { Produced, } P_{n} \\
(\text { TCF/yr) }\end{array}$ & $\begin{array}{l}\text { Price, } K_{n} \\
(\text { \$B/TCF) }\end{array}$ & $\begin{array}{l}\text { Contributio } \\
\text { n Ratio, } Y_{n}\end{array}$ & $\begin{array}{l}\text { Domestic gas } \\
\text { requirement, } D=1.2 \\
(\mathrm{TCF} / \mathrm{yr})\end{array}$ & $\begin{array}{l}\text { Revenue, }(\mathbf{S B} / \mathbf{y r}) \\
D_{n} \times K_{n}\end{array}$ \\
\hline SPDC & $89.773(48.79 \%)$ & $0.1070(7.17 \%)$ & $2.167(52.41 \%)$ & 2.274 & 5.0 & 0.41551 & 0.49861 & 2.49307 \\
\hline $\mathrm{CNL}$ & $25.721(13.98 \%)$ & $0.1740(11.66 \%)$ & $0.604(14.61 \%)$ & 0.778 & 4.8 & 0.13704 & 0.16445 & 0.78937 \\
\hline NAOC & $14.290(7.77 \%)$ & $0.4520(30.30)$ & $0.585(14.15 \%)$ & 1.0375 & 5.2 & 0.14187 & 0.17025 & 0.88530 \\
\hline Total/ELF & $8.7880(4.78 \%)$ & $0.5452(36.55 \%)$ & $0.4175(10.10 \%)$ & 0.962 & 5.2 & 0.12726 & 0.15272 & 0.79414 \\
\hline NPDC/AENR & $1.3770(0.75 \%)$ & $0.0006(0.04 \%)$ & $0.0447(1.08 \%)$ & 0.0453 & 4.5 & 0.00707 & 0.00848 & 0.03818 \\
\hline SNEPCO & $5.4060(2.94 \%)$ & $0.1267(8.5 \%)$ & $0.0142(0.34 \%)$ & 0.1404 & 4.5 & 0.03270 & 0.03924 & 0.17662 \\
\hline MONI-PULO & $1.1990(0.65 \%)$ & $0.0007(0.047 \%)$ & $0.003(0.07 \%)$ & 0.0037 & 5.056 & 0.00356 & 0.00428 & 0.02141 \\
\hline Consolidation OIL & $0.3930(0.21 \%)$ & $0.0000(0.00 \%)$ & $0.0007(0.02 \%)$ & 0.0007 & 5.1 & 0.00111 & 0.00134 & 0.00684 \\
\hline POOCN & $0.2730(0.15 \%)$ & $0.0038(0.25 \%)$ & $0.077(1.86 \%)$ & 0.081 & 5.0 & 0.00683 & 0.00820 & 0.04102 \\
\hline Others & $9.1500(4.97 \%)$ & $0.0720(4.83 \%)$ & 0 & 0.072 & 4.5 & 0.03451 & 0.04142 & 0.18639 \\
\hline Summation & 184.00 & 1.49172 & 4.135 & 5.6257 & 4.98513 & 1.00000 & 1.20000 & 5.98215 \\
\hline
\end{tabular}
Domestic gas contribution and their Revenue from Aggregation. Also assume that the gas prices have been determined to hover around \$5B/TCF and the domestic gas supply obligation is $1.2 \mathrm{scf} / \mathrm{yr}$.

Table 1. Result Template of Domestic Gas Obligation allocation Model.

The 'OTHER' in the table 1 includes company like continental, Atlas, Express, AMNI, NIGER DELTA, NAE and DUBRI whose gas reserves were not spelled out, as a result of insufficient Data.

The revenue from aggregation $R_{A}$ was $\$ 5.982 \mathrm{~B} / \mathrm{yr}$; the aggregated price, $K_{A}=\sum_{i}^{n} K n=4.98513$.

\subsection{The Effect of Gas Reserve on the Domestic Gas Requirement}

The gas reserve shows an expo-linear relationship with the domestic gas requirement as seen below in figure 1; assuming constant value for the total volume of gas utilized by the operating company, $U_{n}(\mathrm{TCF} / \mathrm{yr})$ and for the total volume of gas flared by the operating company, $F_{n}(\mathrm{TCF} / \mathrm{yr})$.

Table 2. Domestic gas Requirement.

\begin{tabular}{lll}
\hline Company & Reservoir, $\boldsymbol{G}_{\boldsymbol{n}}(\mathbf{T C F})$ & Domestic Gas Requirement, $\boldsymbol{D}_{\boldsymbol{n}}$, TSCF \\
\hline SPDC & 30 & 1.2145214 \\
& 25 & 1.176332 \\
20 & 1.125162 \\
15 & 1.055304 \\
10 & 0.943787 \\
5 & 0.758783 \\
\hline
\end{tabular}

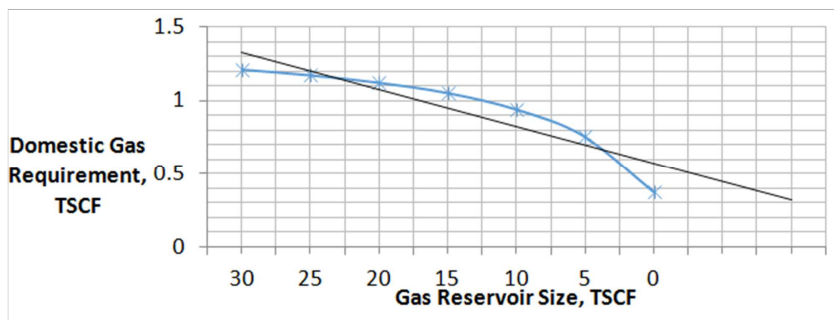

Figure 1. Effect of Gas Reserve on the Domestic Gas Requirement.

It could be seen that the company's domestic gas requirement reduces in an exponential function as the company gas reserves reduces.

\subsection{Comparative Analysis of the Domestic Gas Obligatory Ratio for Different Operating Companies}

It is of note to know that the operating company contributory may change based on what the production and flare is. A change in any of the operators contributing ratio will affect the others in an opposite manner. 


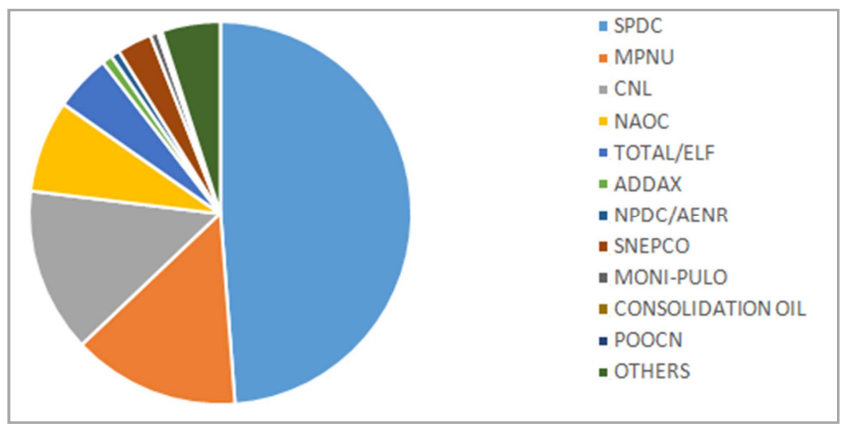

Figure 2. Domestic Gas Obligatory Ratio.

SPDC Nigeria contributes about 50 percent of the gas requirement in Nigeria and as a matter of fact should be regarded as the giant of gas investors in Nigeria.

The Domestic Gas Obligatory Ratio determines what the company's contribution would be in achieving the domestic gas requirement stipulated by the government. This therefore shows that SPDC will be a major contribution to the yearnings of the government.

\subsection{Gas Utilisation Forecast}

The model analysis also portrays what company's requirement has been for year 2008, 2010, 2013 and 2020. This analysis would help the operating company to boast their capacity in achieving this future demand. Refer to Figure 3 below.

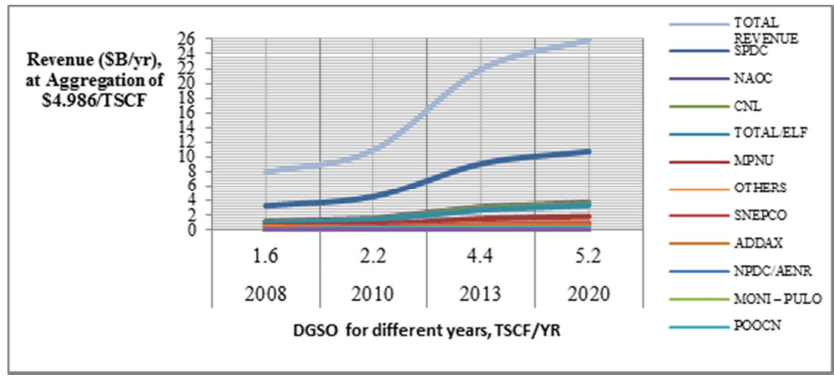

Note: the aggregated price, $K_{A}=\sum_{i}^{n} K n=4.986$.

Figure 3. Comparison of the Revenue accrues from the Domestic Gas Requirement in different years., $K_{A}=4.986$.

The revenue accrues in a given period has shown linear increment signifying growing domestic gas market in Nigeria. The total revenue expected from obliging domestic gas supply obligation in year 2020 is about $\$ 25.992 \mathrm{~B} / \mathrm{yr}$ which in triple magnitude to the total revenue expected in year 2006 and with a difference of about $\$ 17.946 \mathrm{~B} / \mathrm{yr}$. SPDC, NAOC and CNL dominants the gas market and their collective been more than 60 percent of the total revenue from DGSO.

\subsection{Domestic Gas Supply Deficiency and Revenue}

The analysis of the template below shows that some company met with their obligation but there was still gas deficiency since bulk of the operators did not meet up. The Revenue accruable from the DGSO is given in table 3 below.

Table 3. Template for Domestic Gas Supply Deficiency and Revenue.

\begin{tabular}{|c|c|c|c|c|c|}
\hline Company & $\begin{array}{l}\text { Gas Produced, } \\
P_{n}(\mathrm{TCF} / \mathrm{yr})\end{array}$ & $\begin{array}{l}\text { Domestic gas supply, } \\
D_{n_{i}}(\mathrm{TCF} / \mathrm{yr})\end{array}$ & $\begin{array}{l}\text { Domestic gas requirement, } D= \\
2.2(\mathrm{TCF} / \mathrm{yr})\end{array}$ & $\begin{array}{l}\text { Gas Deficit } \\
D_{n}-D_{I},(\mathrm{TCF} / \mathrm{yr})\end{array}$ & $\begin{array}{l}\text { DGSO Penalty Revenue, } \\
\text { (S/yr), Kp*(Dn-Di) }\end{array}$ \\
\hline SPDC & 2.2740 & 0.6822 & 0.91412 & 0.23192 & 0.29333 \\
\hline MPNU & 0.0051 & 0.0015 & 0.15666 & 0.15513 & 0.76581 \\
\hline CNL & 0.7780 & 0.2334 & 0.30149 & 0.06809 & 0.07666 \\
\hline NAOC & 1.0375 & 0.3112 & 0.31212 & 0.00087 & $1.22 \mathrm{E}-05$ \\
\hline TOTAL/ELF & 0.9620 & 0.2886 & 0.27998 & -0.00861 & 0.00132 \\
\hline ADDAX & 0.2260 & 0.0678 & 0.04678 & -0.02101 & 0.04705 \\
\hline SNEPCO & 0.1404 & 0.0421 & 0.07195 & 0.02983 & 0.06167 \\
\hline MONI - PULO & 0.0037 & 0.0011 & 0.00785 & 0.00674 & 0.02886 \\
\hline CONSOLIDATED OIL & 0.0007 & 0.0002 & 0.00246 & 0.00225 & 0.01026 \\
\hline POOCN & 0.0810 & 0.0243 & 0.01504 & -0.00926 & 0.02839 \\
\hline OTHERS & 0.0720 & 0.0216 & 0.07593 & 0.05433 & 0.19382 \\
\hline Summation & 5.6257 & 1.6877 & 2.2 & 0.51229 & 0.59466 \\
\hline
\end{tabular}

Note: $\mathrm{Kp}$ is the penalty price of gas.

The analysis of the table indicates that this model provides an incentive to companies that close the gas deficit gap by reducing their revenue. Therefore it serves as direct incentives to companies who meet with their DGSO.

\section{Conclusion}

This paper efficiently determines what the gas producing companies should supply as contribution to the national grid. The models developed in this study if put into use will ensure a good implementation of the domestic gas supply obligation model would ensure all gas operators in the country would make a mandatory reserves allocation for domestic sector.
The model mandates gas producers to preferentially allocate gas for domestic utilisation prior to export. This will help to develop the natural gas sector and encourage the emergence of many gas utilization projects in the country like modular electricity production, petrochemicals, NGLs, Gas-to-liquids technology, CNG etc. This will greatly increase employment in the country.

\section{Recommendation}

This model and approach to maximise the domestic gas potentials of Nigeria and eradicate gas flare is highly recommended for the producing companies and Nigeria at 
large. The model took care of penalties to be paid for flaring gas and proffered solutions to help reduce flare and help build Nigeria domestic gas market for the industrialization of the country.

\section{References}

[1] Global Gas flaring Reduction Partnership (2018). GGFR Technology Overview - Utilization of Small-Scale Associated Gas.

[2] Nigeria Gas Flare Commercialization Programme (NGFCP). (2018). Request for Qualification. Nigeria: Ministry of Petroleum and natural resources, Nigeria.

[3] Imoudu P. B. and Igbatayo, S. A. (2006), "Developing Nigeria's Gas Industry for Regional Economic Integration: The West African Gas Pipeline Project" SPE 105967, presented at 30th Nigerian Annual International Conference and Exhibition held in Abuja, Nigeria, 3rd - 4th August.

[4] Emejulu, O, FUTO Consult Nigeria Ltd, (2009), "Development of Gas Aggregation and Allocation Models in the Domestic Sector of the Economy" A paper presented at Gas Stakeholders Forum in Abuja, 23th March.

[5] Malcolm, B. (2004), "The vital role of gas in a sustainable energy future", paper presented at CERA conference, Houston. 11th February, 2004.

[6] Neeka, B. J, MPR Nigeria, (2010), "Gas Aggregation and Allocation in the Domestic Sector of the Economy" A paper presented at Gas Stakeholders Forum in Abuja, 15th February.
[7] Morgan L. and Chinwo, C. N. (2006), "Sustainable Gas Utilisation and the Clean Development Mechanism: The Nigerian Perspective" SPE 105968, presented at 30th Nigerian Annual International Conference and Exhibition held in Abuja, Nigeria, 3rd - 4th August.

[8] Kupolokun, F. (2005), Growth Projection for Nigeria's gas sector. An article published in the Nigerian Guardian, 9th may, Lagos.

[9] Okerie, G. A, (2009), "Economic Sustainability of Gas for domestic growth" publication on Oil and Gas Journal (OGJ).

[10] Ogwo A. E, PetroGas Ltd, (2010), "Instruments for the Implementation of Domestic Gas Supply Obligation" A paper presented at Gas Stakeholders Forum in Lagos, 24th February.

[11] Okparaojiaku, O. C, DPR Nigeria (2008), "Domestic Gas Supply Obligation Status" A paper presented at Gas Stakeholders Forum in Lagos, 6th May.

[12] Ogwo, U. J. O, DPR Nigeria, (2008), "A Survey of Existing Gas Prices and Tariff Models in Nigeria" A paper presented at Gas Stakeholders Forum in Abuja, 26th November.

[13] Ogwo, U. J. O, DPR Nigeria, (2007), "Equivalent Gas Pricing Model" SPE 111897, presented at 31st Nigerian Annual International Conference and Exhibition held in Abuja, Nigeria, 6rd - 8th August.

[14] Kazeem L. A., Amam, S. and Yang, J. (2006), "Between Gas Flare-out and Sustainable Oil and Gas TS2" Gas Utilization "SPE 105963, presented at 30th Nigerian Annual International Conference and Exhibition held in Abuja, Nigeria, 3rd - 4th August. 